Article

\title{
Characterization of Whey Protein Oil-in-Water Emulsions with Different Oil Concentrations Stabilized by Ultra-High Pressure Homogenization
}

\author{
Essam Hebishy ${ }^{1,2, *}$, Anna Zamora ${ }^{1}$, Martin Buffa ${ }^{1}$, Anabel Blasco-Moreno ${ }^{3}$ \\ and Antonio-José Trujillo ${ }^{1, *}$ \\ 1 Centre d'Innovació, Recerca i Transfèrencia en Tecnologia dels Aliments (CIRTTA), TECNIO, XaRTA, \\ MALTA Consolider, Departament de Ciència Animal i dels Aliments, Universitat Autònoma de Barcelona, \\ 08193 Bellaterra, Barcelona, Spain; anna.zamora@uab.cat (A.Z.); martin.buffa@uab.cat (M.B.) \\ 2 School of Food and Nutritional Sciences, University College Cork, Cork T12 YN60, Ireland \\ 3 Servei d'Estadística Aplicada, Universitat Autònoma de Barcelona, 08193 Bellaterra, Barcelona, Spain; \\ anabel.blasco@uab.es \\ * Correspondence: essam.hebishy@ucc.ie (E.H.); toni.trujillo@uab.cat (A.-J.T.); Tel.: +353-21-4903625 (E.H.); \\ +34-93-581-3-92 (A.-J.T.); Fax: +34-93-581-20-06 (A.-J.T.)
}

Academic Editor: Andreas Håkansson

Received: 1 October 2016; Accepted: 30 January 2017; Published: 10 February 2017

\begin{abstract}
In this study, the effect of ultra-high-pressure homogenization (UHPH: 100 or $200 \mathrm{MPa}$ at $25^{\circ} \mathrm{C}$ ), in comparison to colloid mill (CM: $5000 \mathrm{rpm}$ at $20^{\circ} \mathrm{C}$ ) and conventional homogenization (CH: $15 \mathrm{MPa}$ at $60^{\circ} \mathrm{C}$ ), on the stability of oil-in-water emulsions with different oil concentrations $(10,30$ or $50 \mathrm{~g} / 100 \mathrm{~g})$ emulsified by whey protein isolate $(4 \mathrm{~g} / 100 \mathrm{~g})$ was investigated. Emulsions were characterized for their microstructure, rheological properties, surface protein concentration (SPC), stability to creaming and oxidative stability under light $\left(2000 \mathrm{lux} / \mathrm{m}^{2}\right)$. UHPH produced emulsions containing lipid droplets in the sub-micron range (100-200 nm) and with low protein concentrations on droplet surfaces. Droplet size $(\mathrm{d} 3.2, \mu \mathrm{m})$ was increased in $\mathrm{CH}$ and $\mathrm{UHPH}$ emulsions by increasing the oil concentration. $\mathrm{CM}$ emulsions exhibited Newtonian flow behaviour at all oil concentrations studied; however, the rheological behaviour of $\mathrm{CH}$ and $\mathrm{UHPH}$ emulsions varied from Newtonian flow $(n \approx 1)$ to shear-thinning $(n<1)$ and thixotropic behaviour in emulsions containing $50 \%$ oil. This was confirmed by the non-significant differences in the $\mathrm{d} 4.3(\mu \mathrm{m})$ value between the top and bottom of emulsions in tubes left at room temperature for nine days and also by a low migration velocity measured with a Turbiscan LAB instrument. UHPH emulsions showed significantly lower oxidation rates during 10 days storage in comparison to $\mathrm{CM}$ and $\mathrm{CH}$ emulsions as confirmed by hydroperoxides and thiobarbituric acid-reactive substances (TBARS). UHPH emulsions treated at $100 \mathrm{MPa}$ were less oxidized than those treated at $200 \mathrm{MPa}$. The results from this study suggest that UHPH treatment generates emulsions that have a higher stability to creaming and lipid oxidation compared to colloid mill and conventional treatments.
\end{abstract}

Keywords: ultra-high pressure homogenization (UHPH); whey protein; submicron emulsions; physical and oxidative stabilities

\section{Introduction}

Oils can become oxidized during processing, distribution and handling, particularly if they are highly unsaturated [1,2]. Lipid oxidation in formulated foods is therefore a major concern to food producers. Modern consumers have a preference for 'clean label' food products with little to no additives present, e.g., synthetic antioxidants and emulsifiers; thus, it is important to develop new processing technologies that reduce the need of using stabilizing additives. 
Oil-in-water $(\mathrm{O} / \mathrm{W})$ submicron/nano-emulsions have been studied in order to encapsulate lipophilic molecules in the food, pharmaceutical and cosmetic sectors [3,4]. Emulsion stability depends on a range of complex mechanisms, including flocculation, coalescence, Ostwald ripening and phase separation. However, it is well known that one of the key factors determining stability is the average size of fat globules and their size distribution [5]. Submicron (nano) emulsions are systems containing droplets with diameters below $1 \mu \mathrm{m}$ and are known to have a high physical stability [6]. Producing emulsions with small droplet sizes and narrow size distributions can be achieved through the application of a large amount of energy, or the use of surfactants, or the combination of both. Low-energy emulsification processes, such as phase-inversion temperature techniques, require the use of large quantities of surfactants; thus, they cannot be used for large-scale industrial production [7]. High-energy emulsification utilizes mechanical devices, such as high-pressure homogenizers and microfluidizers or sonication equipment, that are being used in industrial production. These technologies generate intense disruptive forces that break up the oil and water phases and lead to the formation of small oil droplets [8]. Ultra-high-pressure homogenization (UHPH) is a non-thermal processing technique, which works at significantly higher pressures $(\geq 200 \mathrm{MPa})$ than high-pressure homogenization (150-200 Mpa) or microfluidization (20-150 MPa) [9,10].

The physical characteristics and emulsion stability of nutritional formulations were evaluated on a pilot-scale HPH unit [11]. The authors reported that homogenization at pressures from 100-150 MPa yielded more shear-thinning fluids with increased physical stability, representing an opportunity to reduce the concentration of stabilizers in dairy beverages. In another study, UHPH (100-300 MPa) was compared to conventional homogenization at $15 \mathrm{MPa}$ and was found to produce oil-in-water emulsions containing $4.0 \%(w / v)$ of soy protein isolate (SPI) and soybean oil (10\% and $20 \%, v / v)$ with small $\mathrm{d} 3.2(\mu \mathrm{m})$ values and great physical stability [12]. Kuhn and Cunha [13] studied the effects of homogenization pressure and the number of homogenization cycles on the physicochemical characteristics of emulsions containing flaxseed oil and whey protein isolate. The authors reported that these emulsions showed good physical stability without phase separation after nine days of storage, when homogenized at high-pressure (20-100 MPa) with 1-7 homogenization cycles.

Proteins are ingredients widely used in food emulsions as emulsifiers/stabilizers due to their amphiphilic character. Proteins are able to form an interfacial layer that generates repulsive forces (e.g., steric and electrostatic) between oil droplets, which plays an important role in stabilizing the droplets against flocculation and coalescence during long-term storage [14]. Whey protein isolates (WPI) are widely used as emulsifiers to enhance the formation and stability of $(\mathrm{O} / \mathrm{W})$ emulsions $[15,16]$. Whey proteins are also known to inhibit lipid oxidation by preventing pro-oxidants from accessing the droplets [17].

The oil volume fraction has a great influence on the physicochemical and viscoelastic properties of emulsions by affecting droplet size distribution, creaming, oxidative stability and rheological properties [18]. Few data are available concerning the combined effects of varying dynamic high-pressure treatments and the oil volume fraction on emulsion rheology and physical stability. Cortés-Muñoz et al. [19] studied oil concentrations of $15 \%, 30 \%$ and $45 \%$ and pressures up to $300 \mathrm{MPa}$ in $\mathrm{O} / \mathrm{W}$ emulsions stabilized by whey protein isolate $(4 \%)$, reporting that optimal droplet breakdown was observed for emulsions with $30 \%$ of oil $(w / w)$ treated with homogenization pressures $\geq 200 \mathrm{MPa}$. Floury et al. [20] reported that increasing oil concentration resulted in a larger mean droplet diameter at constant homogenizing conditions due to the limitation of the emulsifier. These researchers revealed that the emulsions containing less than $20 \%$ of oil followed Newtonian behaviour $(n=1)$ regardless of the homogenization pressure applied; however, emulsions containing more than $20 \%$ of oil and homogenized at 20 or 150 MPa showed shear-thinning behaviours $(n<1)$. Floury et al. [20] also showed that the application of increasing homogenization pressures resulted in high oil content emulsions $(>40 \%$ ) transitioning from shear-thinning behaviour (at $20 \mathrm{MPa}$ ) to Newtonian behaviour (at $300 \mathrm{MPa}$ ).

It is well established that emulsions with small droplet sizes and high specific surface areas are very sensitive to lipid oxidation [21]. Many other factors may affect the oxidative stability of 
nano-emulsions, such as the physical structure of emulsions, the level and type of emulsifier(s) or the bulk oil-phase [22]. However, there are few studies that have investigated the oxidative deterioration of these emulsions, including those containing high oil concentrations.

In a previous work of the present authors [23], submicron emulsions with high physical and oxidative stabilities were obtained using 1 or $2 \mathrm{~g}$ WPI /100 $\mathrm{g}$ and $100 \mathrm{MPa}$ homogenization pressure or $4 \mathrm{~g}$ WPI /100 g and $200 \mathrm{MPa}$ homogenization pressure. Fernandez-Avila and Trujillo [24] reported that soy protein isolate stabilized emulsions containing $20 \%$ of oil $(w / v)$, rather than $10 \%(w / v)$, with homogenization pressures of 100 or $200 \mathrm{MPa}$ from the point of view of oxidation. The researchers attributed this high oxidative stability to the large quantity of oil and the high protein load at the surface. However, to the knowledge of the present authors, no reports on the effect of oil concentration and homogenization pressure on the oxidative stability of whey protein-stabilized emulsions have been referred in the literature. Further research is required to establish the relationship between UHPH treatment of emulsions and the stability to lipid oxidation. The objective of this study was to evaluate the effect of homogenization pressures (100-200 MPa) and oil concentration (10, 30 and $50 \mathrm{~g} / 100 \mathrm{~g}$ ) on the structure, rheological properties, physical and oxidative stabilities of emulsions containing $4 \mathrm{~g}$ whey protein isolate $/ 100 \mathrm{~g}$, in comparison with those produced by colloid mill and conventional homogenization.

\section{Materials and Methods}

\subsection{Materials}

Whey protein isolate (WPI) was obtained from Lactalis (Prolacta 90, Retiers, France). The WPI contained $95.9 \mathrm{~g}$ dry solids per $100 \mathrm{~g}$ powder and, on a dry basis $(w / w), 1.04 \%$ non-protein nitrogen $(\mathrm{NPN}), 89.3 \%$ protein $(($ total $\mathrm{N}-\mathrm{NPN}) \times 6.38), 1.1 \%$ ash (including $0.27 \%$ calcium) and $1.6 \%$ lactose, as given by the producer. Protein constituents in the WPI corresponded mainly to $\beta$-lactoglobulin ( $\beta$-Lg) and $\alpha$-lactalbumin ( $\alpha$-La) (i.e., $68.5 \% \beta$-Lg and $21.5 \% \alpha$-La per $100 \mathrm{~g}$ soluble protein) with small amounts or traces of immune globulins, bovine serum albumin and lactoferrin.

Refined sunflower and olive oils were purchased from Gustav Heess Company (Barcelona, Spain). The characteristics and composition of oils according to the producer were: density $\left(20{ }^{\circ} \mathrm{C}\right)=0.921$ and 0.913 ; acid value $=0.09(\mathrm{mg} \mathrm{KOH} / \mathrm{g})$ and $0.11 \%$; peroxide value $\left(\right.$ meq $\left.\mathrm{O}_{2} / \mathrm{kg}\right)=0.02$ and 0.5 ; absorbance $(270 \mathrm{~nm})=$ not determined and 0.29 ; unsaponifiable $(\% \mathrm{~m} / \mathrm{m})=<0.05 \%$ and $<1.5 \% ; \mathrm{C} 16: 0$ $(\%)=6.34$ and $11.94 ; \mathrm{C} 18: 0(\%)=3.97$ and $3.30 ; \mathrm{C} 18: 1(\%)=26.65$ and $75.23 ; \mathrm{C} 18: 2(\%)=61.02$ and 6.75 ; $\mathrm{C} 18: 3(\%)=0$ and 0.38 ; for sunflower and olive oils, respectively.

\subsection{Preparation of Emulsions}

\subsubsection{Experimental Design}

A completely randomized factorial design was applied to study the influence of homogenization pressure and oil concentration on the physical and oxidative stability of the emulsions. This design was used with three homogenization methods (colloid mill (CM), conventional homogenization $(\mathrm{CH})$ and ultra-high pressure homogenization ( $\mathrm{UHPH})$ ). By varying the shear rate (5000 rpm for $\mathrm{CM}$ ) or homogenization pressure (15 MPa for $\mathrm{CH}$ and 100, $200 \mathrm{MPa}$ for UHPH) and oil concentration $(10,30$ and $50 \mathrm{~g} / 100 \mathrm{~g})$ according to Table 1, twelve samples were formulated. Prepared samples were stored in glass bottles under refrigeration $\left(4^{\circ} \mathrm{C}\right)$ until physical analyses. Oxidation analyses were carried out on the first and last day of a 10-day storage at $10^{\circ} \mathrm{C}$ in clear glass bottles under light $\left(2000 \mathrm{lux} / \mathrm{m}^{2}\right)$. 
Table 1. Experimental design used in emulsion formulation. $\mathrm{CM}$, colloid mill; $\mathrm{CH}$, conventional homogenization.

\begin{tabular}{ccccc}
\hline Treatments & (Homogenization Method) & Homogenization Level & (Oil Content \%) & Inlet Temperature $\left({ }^{\circ} \mathbf{C}\right)$ \\
\hline 1 & $\mathrm{CM}$ & $5000 \mathrm{rpm}$ & 10 & 20 \\
2 & $\mathrm{CM}$ & $5000 \mathrm{rpm}$ & 30 & 20 \\
3 & $\mathrm{CM}$ & $5000 \mathrm{rpm}$ & 50 & 20 \\
4 & $\mathrm{CH}$ & $15 \mathrm{MPa}$ & 10 & 60 \\
5 & $\mathrm{CH}$ & $15 \mathrm{MPa}$ & 30 & 60 \\
6 & $\mathrm{CH}$ & $100 \mathrm{MPa}$ & 50 & 25 \\
7 & $\mathrm{UHPH}$ & $100 \mathrm{MPa}$ & 10 & 25 \\
8 & $\mathrm{UHPH}$ & $100 \mathrm{MPa}$ & 30 & 25 \\
9 & $\mathrm{UHPH}$ & $500 \mathrm{MPa}$ & 50 & 25 \\
10 & $\mathrm{UHPH}$ & $200 \mathrm{MPa}$ & 30 & 25 \\
11 & $\mathrm{UHPH}$ & $200 \mathrm{MPa}$ & 50 & 25 \\
\hline
\end{tabular}

\subsubsection{Preparation of Protein Dispersions}

WPI dispersions containing $4 \mathrm{~g}$ WPI/100 g were prepared in deionized water using agitation with a high speed mechanical blender (Frigomat, Guardamiglio, Italy) at a rate of $250 \mathrm{rpm}$ at $20{ }^{\circ} \mathrm{C}$. Protein dispersions with $\mathrm{pH} \approx 6.5-7$ (MicropH 2001, Crison, Alella, Spain) were stored overnight at $4{ }^{\circ} \mathrm{C}$ to allow protein hydration.

\subsubsection{Homogenization Treatments}

After rehydration, protein dispersions of $4 \mathrm{~g}$ WPI/100 $\mathrm{g}$ and different oil concentrations $(10,30$ and $50 \mathrm{~g} / 100 \mathrm{~g})$ were equilibrated at $20^{\circ} \mathrm{C}$ before mixing. Pre-emulsions (or coarse emulsions) were prepared by mixing the oily dispersed phase (3 parts sunflower:1 part olive oil) with the aqueous continuous phase containing WPI at room temperature to give a total volume of $40 \mathrm{~L}$. The mixture was stirred for 5 min using a colloid mill homogenizer (E. Bachiller B, S.A, Barcelona, Spain) at maximum power (5000 rpm) to obtain the CM emulsions and further processed into $\mathrm{CH}$ and UHPH emulsions as follows.

Conventional homogenization of the CM emulsions was performed using an APV Rannie Copenhagen Series Homogenizer (Model 40.120 H, single-stage hydraulic valve assembly, Copenhagen, Denmark) with $T_{\text {in }}$ of $60{ }^{\circ} \mathrm{C}$ at $15 \mathrm{MPa}(\mathrm{CH}$ emulsions).

CM emulsions were treated by UHPH using a Stansted high-pressure homogenizer (Model/DRG number FPG 11,300:400 Hygienic Homogenizer, Stansted Fluid Power Ltd., Harlow, UK) with a flow rate of $120 \mathrm{~L} / \mathrm{h}$ as indicated by the manufacturer. Two spiral-type heat exchangers (Garvía, Barcelona, Spain) located behind the second valve were used to cool the emulsion immediately after the HP-valve to minimize temperature retention in the emulsion after treatment, which may affect emulsion composition. Emulsions were UHPH-treated at pressures of 100 and $200 \mathrm{MPa}$ (single-stage) with an inlet temperature $\left(T_{\text {in }}\right)$ of $25{ }^{\circ} \mathrm{C}$ (UHPH emulsions). Throughout the experiment, the $T_{\text {in }}$ the temperature after the homogenization valve $(T 1)$ and the temperature of the outlet product $(T 2)$ were monitored.

The experiment by each preparation method in each study was repeated three times.

\subsection{Emulsion Measurements and Analyses}

\subsubsection{Droplet Size Distribution}

The droplet size distribution of the different emulsions was determined just after sample preparation using a Beckman Coulter laser diffraction particle size analyser (LS 13320 series, Beckman Coulter, Fullerton, CA, USA), as described by Hebishy et al. [23]. Emulsion samples were diluted in distilled water until an appropriate obscuration was obtained in the diffractometer cell. An optical model based on the Mie theory of light scattering by spherical droplets was applied by 
using the following conditions: real refractive index of the oil mixture (sunflower oil:olive oil (3:1)), which was obtained by a refractometric measurement (Spectronic Instruments, Inc., Rochester, NY, USA), 1.471; refractive index of fluid (water), 1.332; the refractive index of the protein was assumed to be 0 [25]; imaginary refractive index, 0 ; pump speed, $20 \%$. The volume weighted mean diameter $(\mathrm{d} 4.3, \mu \mathrm{m})$, surface-weighted mean diameter $(\mathrm{d} 3.2, \mu \mathrm{m})$ and specific surface area $\left(\mathrm{SSA}, \mathrm{m}^{2} / \mathrm{mL}\right)$ were determined. Each diluted sample was analysed at least four times in succession to obtain a mean size distribution curve and the corresponding mean values.

\subsubsection{Surface Protein Concentration}

The surface protein concentration of oil droplets was determined according to the method of Desrumaux and Marcand [26], as described by Hebishy et al. [23]. Briefly, the cream layer was isolated by centrifugation and clarified. The protein content of the isolated purified protein layers was determined in triplicate by the Dumas method with a Leco FP-528 nitrogen/protein instrument (Leco Corp., St. Joseph, MI, USA), estimating crude protein content as $\mathrm{N} \times 6.38$.

\subsubsection{Rheological Measurements}

Rheological measurements were performed at $25{ }^{\circ} \mathrm{C}$ using a controlled stress rheometer (Haake Rheo Stress 1, Thermo Electron Corporation, Karlsruhe, Germany) with a parallel plate geometry probe $\left(1^{\circ}, 60 \mathrm{~mm}\right.$ diameter). To avoid any structure destruction, samples were left standing for $5 \mathrm{~min}$ at $25^{\circ} \mathrm{C}$ in order to reach equilibrium. Flow curves were fitted to the Ostwald de Waele rheological model: $\tau=K \cdot \gamma^{n}$, and the consistency coefficient $(K, \mathrm{mPa} \times \mathrm{s})$ and flow behaviour index $(n)$ were obtained. Rheological measurements were carried out in triplicate.

\subsubsection{Physical Stability}

The physical stability of emulsions was assessed by measuring the $d 4.3(\mu \mathrm{m})$ value at the top or at the bottom of the emulsion tubes stored for 9 days. Measurements were performed in triplicate using the laser diffraction particle size analyser (LS 13320 series, Beckman Coulter, Fullerton, CA, USA), as detailed before (Section 2.3.1).

The stability of emulsions was also determined with a vertical scan analyser Turbiscan MA 2000 (Formulaction, Toulouse, France), as reported by Hebishy et al. [23]. This equipment allows the optical characterization of any type of dispersion. The light source is an electro-luminescent diode in the near-infrared ( $\lambda$ air $=850 \mathrm{~nm}$ ). Any change due to a variation of the droplet size (flocculation, coalescence) or a local variation of the volume fraction (migration phenomena: creaming, sedimentation) is detected. Under backscattering mode, Turbiscan measures the light backscattered by the sample, which is directly dependent on the droplet mean diameter, at pre-set intervals (30 min for $\mathrm{CM}$ emulsions, 3 days for $\mathrm{CH}$ and $\mathrm{UHPH}$ emulsions) over a selected period of time ( $5 \mathrm{~h}$ for $\mathrm{CM}$ emulsions and 17 days for $\mathrm{CH}$ and $\mathrm{UHPH}$ emulsions). The migration rate or velocity $(V ; \mu \mathrm{m} / \mathrm{min})$ of the clarification front was also calculated using Turbisoft software in order to follow the kinetics of the creaming phenomenon.

\subsubsection{Emulsion Microstructure}

In order to assess the microstructure of emulsions, emulsion samples were observed under a transmission electron microscope with a Jeol 1400 (Jeol Ltd., Tokyo, Japan) equipped with a Gatan Ultrascan ES1000 CCD Camera. Samples were prepared according to Cruz et al. [27], as described by Hebishy et al. [23].

\subsubsection{Stability of Emulsions to Photo-Oxidation}

For the determination of primary oxidation products, lipid hydroperoxides were measured by mixing $0.3 \mathrm{~mL}$ of emulsion with $1.5 \mathrm{~mL}$ of isooctane/2-propanol $(3: 1, v / v)$ by vortexing $(10 \mathrm{~s}$, 
three times) and isolating the organic solvent phase by centrifugation at $1000 \times g$ for $2 \mathrm{~min}$. The organic solvent phase $(200 \mu \mathrm{L})$ was added to $2.8 \mathrm{~mL}$ of methanol/1-butanol $(2: 1, v / v)$, followed by $15 \mu \mathrm{L}$ of $3.97 \mathrm{M}$ ammonium thiocyanate and $15 \mu \mathrm{L}$ of ferrous iron solution (prepared by mixing $0.132 \mathrm{M} \mathrm{BaCl}_{2}$ and $0.144 \mathrm{M} \mathrm{FeSO}_{4}$ ). The absorbance of the solution was measured at $510 \mathrm{~nm}, 20 \mathrm{~min}$ after the addition of the iron [28]. Hydroperoxide content was expressed as absorbance (A510).

For the determination of secondary oxidation products, thiobarbituric acid-reactive substances (TBARS) were determined according to an adapted method of McDonald and Hultin [29]. The emulsion $(1.0 \mathrm{~mL})$ was combined with $2.0 \mathrm{~mL}$ of TBA solution (prepared by mixing $15 \mathrm{~g}$ of trichloroacetic acid, $0.375 \mathrm{~g}$ of thiobarbituric acid, $1.76 \mathrm{~mL}$ of $12 \mathrm{~N} \mathrm{HCl}$ and $82.9 \mathrm{~mL}$ of $\mathrm{H}_{2} \mathrm{O}$ ) in test tubes and placed in a boiling water bath for $15 \mathrm{~min}$. The tubes were allowed to cool to room temperature for $10 \mathrm{~min}$, and then, the coloured solution was separated by filtration through glass wool. The absorbance was measured at $532 \mathrm{~nm}$. Concentrations of TBARS were calculated from a standard curve prepared using 1,1,3,3-tetraethoxypropane.

\subsection{Statistical Analyses}

Statistical analyses were performed using SAS System ${ }^{\circledR}$ v9.2 (SAS Institute Inc., Cary, NC, USA), with a nominal significance level of $5 \%(p<0.05)$ and Tukey adjustment for multiple comparisons of means. In order to evaluate the physical and oxidative stabilities depending on the type of emulsion (CM, CH or UHPH) and the concentration of oil $(10 \%, 30 \%$ and $50 \%)$, a general linear model with repeated measures was performed. The rheological index, consistency coefficient, hydroperoxides and TBARS values were compared between the $\mathrm{CM}, \mathrm{CH}$ and UHPH emulsions. The other parameters (d3.2, SSA and SPC) were compared only between $\mathrm{CH}$ and UHPH emulsions, excluding CM emulsions due to the wide variation of data; these three parameters were compared among the three oil levels in CM emulsions.

\section{Results and Discussion}

\subsection{Droplet Size Distribution}

The droplet size $(\mathrm{d} 3.2, \mu \mathrm{m})$ and specific surface area $\left(\mathrm{SSA}, \mathrm{m}^{2} / \mathrm{mL}\right)$ for emulsions containing $4 \mathrm{~g}$ WPI/100 $\mathrm{g}$ and different oil concentrations (10,30 and $50 \mathrm{~g} / 100 \mathrm{~g})$ are shown in Table 2 and Figure $1 \mathrm{~A}$. $\mathrm{CM}$ emulsions, at all oil concentrations, had large droplet sizes $(\sim 6 \mu \mathrm{m})$, as can be observed in the TEM micrograph (Figure 1B(i)). When increasing from $10 \%-30 \%$ and to $50 \%$, oil concentration significantly affected $(p<0.05)$ droplet size in CM emulsions, decreasing d3.2 $(\mu \mathrm{m})$, as can be seen from their size distribution curves (Figure 1A).

Applying the conventional homogenization at $15 \mathrm{MPa}$ significantly decreased $(p<0.05)$ the droplet size to the nano range. However, greater d $3.2(\mu \mathrm{m})$ were observed when the oil content increased from $10 \%-30 \%$ and $50 \%$ (Table 2), as evidenced by TEM images (Figure 2A-C). This phenomenon was accompanied by a concomitant and significant change $(p<0.05)$ in the surface protein concentration of $\mathrm{CH}$ emulsions (Table 2).

Concerning the effect of UHPH, treatments performed at $200 \mathrm{MPa}$ were more effective in reducing droplet size than those at $100 \mathrm{MPa}$, as can be seen from TEM images (Figure 2G-L). Similar results have been obtained when applying the same homogenization pressures to soymilk or cow milk $[27,30]$. A previous study of the present authors showed that although pressures of up to $200 \mathrm{MPa}$ were effective in decreasing the droplet size of emulsions with $4 \mathrm{~g}$ WPI/100 $\mathrm{g}(w / v)$ and $20 \mathrm{~g} / 100 \mathrm{~g}$ of oil content, increasing the pressure to $300 \mathrm{MPa}$ tended to increase the droplet size [23].

UHPH emulsions treated at $100 \mathrm{MPa}$ and containing $10 \%$ of oil exhibited small droplet sizes (Table 2) and monomodal distributions (Figure 1A(iii)). As the oil content was increased, droplets became larger with a concomitant decrease of their SSA. However, these changes were only significant $(p<0.05)$ in emulsions containing $50 \%$ oil, whose distribution curves changed to bimodal. The increase in droplet size may be attributed to a high degree of flocculation (Figure 2I). 
As the oil content increased to $30 \%$ in emulsions treated at $200 \mathrm{MPa}$, the UHPH was able to produce monomodal distributions (Figure 1A(iv)), but was unable to achieve a narrow size distribution. Increasing the oil content to $50 \%$ in emulsions treated at $200 \mathrm{MPa}$ clearly shifted the curve to bimodal with a wider size distribution (Figure 1A(iv)). As can be observed from the TEM images (Figure 2J-L), flocculation or coalescence is likely to be responsible for the large droplet sizes observed in emulsions treated at $200 \mathrm{MPa}$ containing 50\% oil. The bimodal distribution in these emulsions may be due to an over-processing phenomena affecting the flocculation of the newly-created fine droplets in the homogenization chamber or during pressure release. This phenomenon may happen when the surfactant concentration is not sufficient to cover the newly-created surface [31].
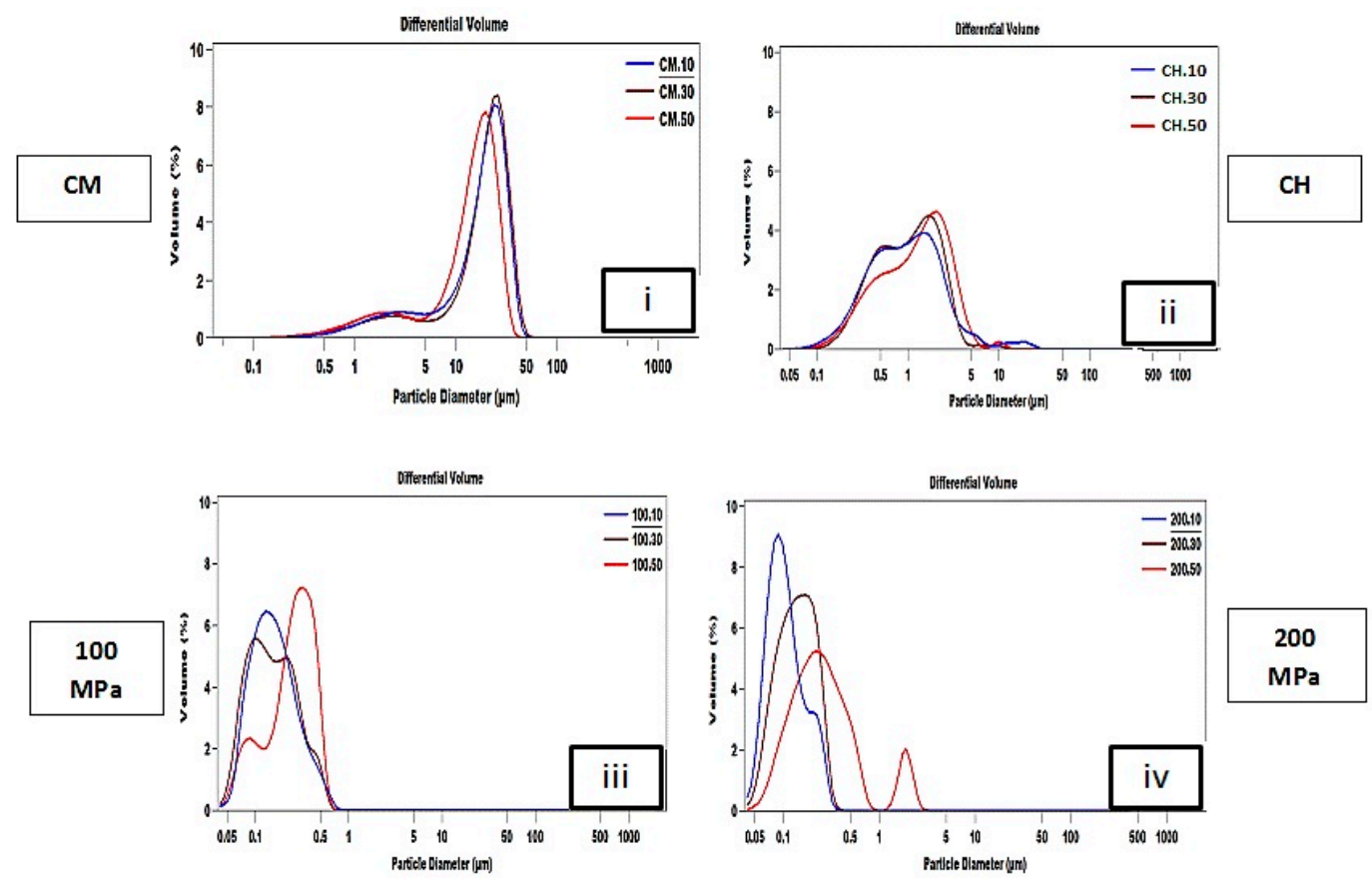

(A)

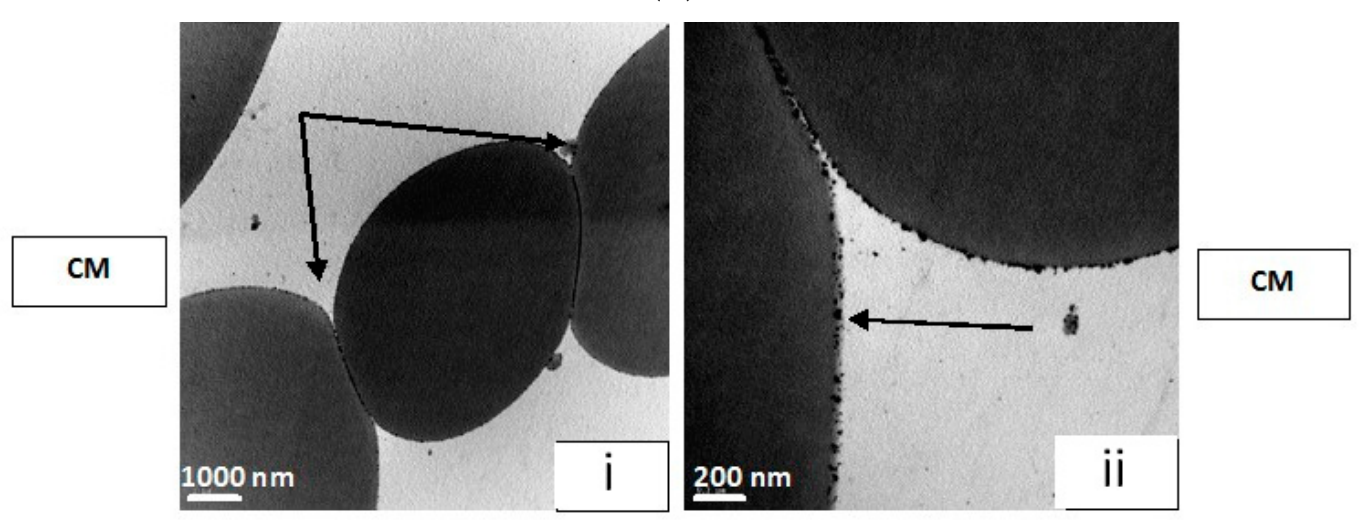

(B)

Figure 1. (A) Droplet size distribution curves measured by light scattering of oil-in-water $(\mathrm{O} / \mathrm{W})$ emulsions containing $10 \%, 30 \%$ and $50 \%$ oil plus $4 \%$ whey protein isolates (WPI) processed by (i) CM, (ii) $\mathrm{CH}$ and UHPH at (iii) 100 and (iv) $200 \mathrm{MPa}$; (B) TEM images of O/W emulsions stabilized by CM (i,ii) containing $30 \%$ oil (i) $\times 10,000$ and (ii) $\times 50,000$, respectively.

Several reasons may explain the increase of droplet size with increasing volume fraction: (1) higher oil concentrations increase the emulsion viscosity, and thereby, droplet disruption might become more 
difficult [32]; (2) an inadequate amount of protein in the aqueous phase may cause some aggregation of fat globules [33]; and (3) the rate of collision frequency and thus coalescence frequency may increase as the oil content increases [34]. The results of the present study are in agreement with the results that have been reported for emulsions containing different oil concentrations with whey proteins as emulsifiers. Cortés-Muñoz et al. [19] studied the submicron emulsion characteristics using 15\%-45\% of oil and pressures up to $300 \mathrm{MPa}$. They reported that the best droplet breakdown was achieved when the pressure used was less than $225 \mathrm{MPa}$ with $30 \%$ of oil. These researchers attributed this result to the increase in the fluid viscosity at the valve gap outlet since it may shift the flow pattern from turbulent to transitional, reducing therefore cavitation and impact phenomena and limiting droplet re-agglomeration and coalescence. Fernández-Ávila et al. [12] studied the effect of UHPH (100-300 MPa) on the physicochemical properties of oil-in-water emulsions prepared with $4.0 \%(w / v)$ of soy protein isolate and soybean oil $(10 \%$ and $20 \%, v / v)$. The authors reported that at a constant emulsification pressure, $\mathrm{d} 3.2(\mu \mathrm{m})$ rose with increasing oil content.
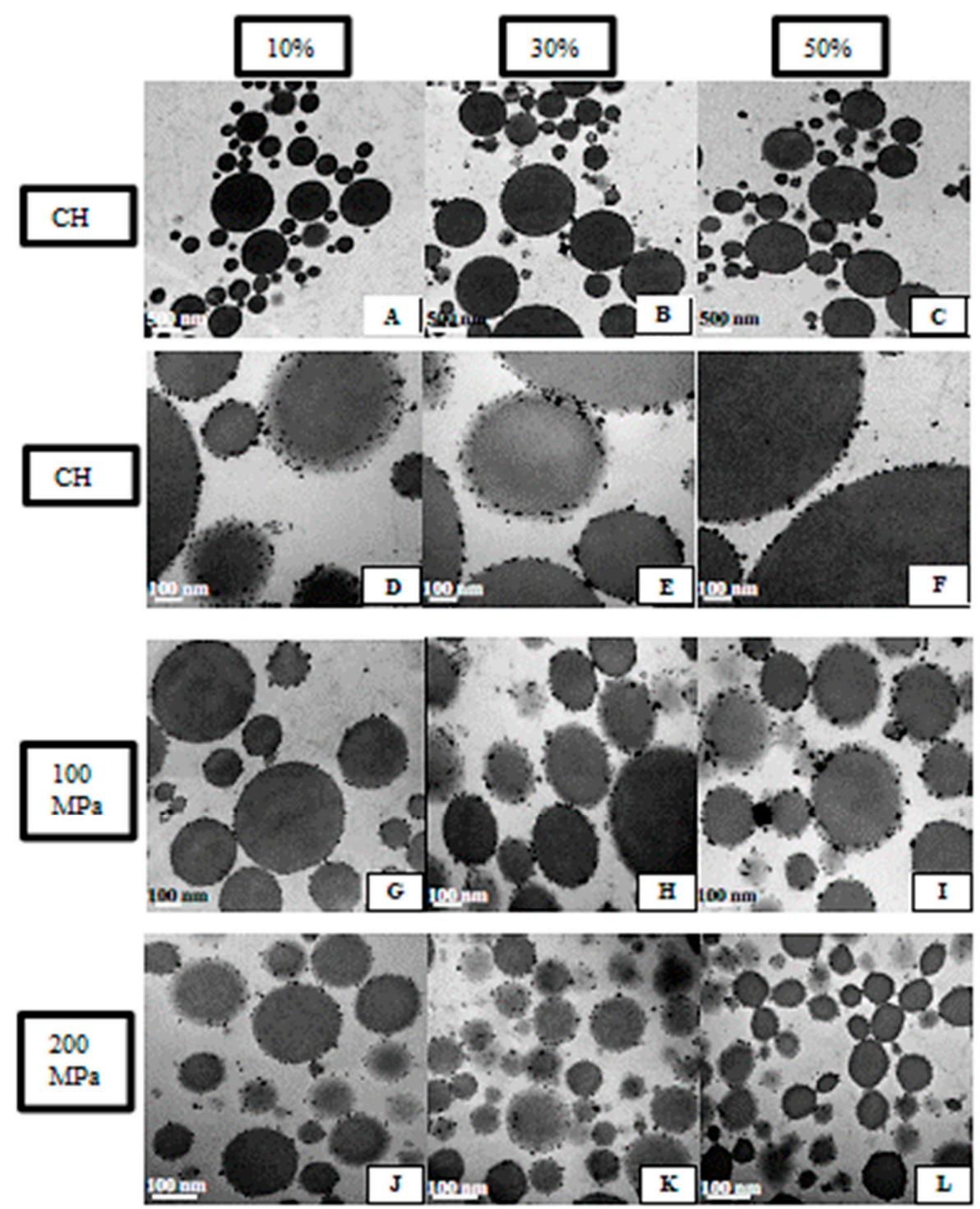

Figure 2. TEM images of emulsions containing $10 \%, 30 \%$ and $50 \%$ oil and WPI $4 \%$ stabilized by $\mathrm{CH}$ at $15 \mathrm{MPa}(\mathbf{A}-\mathbf{C}) \times 100,000$ and $(\mathbf{D}-\mathbf{F}) \times 25,000$ and by $\mathrm{UHPH} \times 100,000$ at $100 \mathrm{MPa}(\mathbf{G}-\mathbf{I})$ and $200 \mathrm{MPa}$ (J-L), respectively. 


\subsection{Surface Protein Concentration}

Table 2 shows the amount of protein adsorbed at the emulsion droplet surface. High protein amounts $\left(\mathrm{mg} / \mathrm{m}^{2}\right)$ were observed in CM emulsions, as a result of high droplet size and low SSA. The amount of protein adsorbed at the interface of an emulsion droplet suggests the state of the protein adsorbed at the interface. If the protein load is $\sim 1 \mathrm{mg} / \mathrm{m}^{2}$, which is the case of UHPH emulsions; it indicates that the protein molecules are fully unfolded. If the protein load is $1-3 \mathrm{mg} / \mathrm{m}^{2}$ (as for CH emulsions), a monolayer of globular proteins may be present or unfolded molecules may be adsorbed in the conformation of trains, loops and tails. A protein load above $5 \mathrm{mg} / \mathrm{m}^{2}$ (such as CM emulsions) indicates adsorption of aggregates of proteins or multilayers of proteins [35-37].

At first glance, it would seem reasonable to think that UHPH emulsions had lower protein load than $\mathrm{CM}$ and $\mathrm{CH}$ emulsions since they had significantly lower $(p<0.05)$ surface protein concentrations. However, and taking into account the SSA of droplets, which was significantly higher for UHPH compared with both $\mathrm{CM}$ and $\mathrm{CH}$, the amount of surface protein per volume (millilitre) would be much higher in UHPH emulsions (41 and $53.51 \mathrm{mg} / \mathrm{mL}$ at 100 and $200 \mathrm{MPa}$, respectively) than in CM and $\mathrm{CH}$ emulsions (23.30 and $25.80 \mathrm{mg} / \mathrm{mL}$, respectively). This may be attributed to the increased spreading and rearrangement of adsorbed protein molecules at the interface. High homogenization pressures may modify the properties of any protein and especially serum proteins by modifying their 3D structures [38] and thus facilitate their adsorption at the interface, as suggested by Dalgleish [36].

Concerning the effect of oil content on the SPC, as shown in Table 2, increasing oil concentration in $\mathrm{CM}$ emulsions resulted in a strong linear decrease in the SPC, probably due to the decrease in the droplet size and the concomitant increase in the SSA. The higher the surface area formed during homogenization, the higher the amount of protein needed to obtain a full coverage of the droplets. In $\mathrm{CH}$ emulsions, increasing the oil content from $10 \%-30 \%$ resulted in a significant increase in the SPC, possibly due to the significant increase $(p<0.05)$ in the droplet size and the decrease in the SSA. But further increases in the oil content to $50 \%$ decreased significantly $(p<0.05)$ the SPC, which might be due to the limited protein availability to cover the newly-created interface. In fact, TEM images (Figure 2D-F) showed a dense interfacial layer very apparent in emulsions containing $10 \%$ and $30 \%$ oil, but imperceptible in those containing 50\% oil. SPC reduction as oil content increases may be the predominant factor that promoted flocculation. Considering UHPH, both at 100 and $200 \mathrm{MPa}$, the oil concentration did not have any significant effect on the SPC.

\subsection{Rheological Behaviour}

Low viscosities and Newtonian behaviour were observed for all $\mathrm{CM}$ emulsions and for $\mathrm{CH}$ emulsions containing only $10 \%$ or $30 \%$ oil, which could be explained by a low degree of interactions between droplets. However, high consistency coefficient $(K)$ values and shear-thinning behaviour or pseudo-plasticity were observed in $\mathrm{CH}$ emulsions when the oil concentration increased to $50 \%$ (Table 2). In the case of UHPH emulsions, the apparent viscosity increased and could be explained by an increase in droplet interactions. 
Table 2. Mean $\pm \mathrm{SD}$ of droplet size distribution $(\mathrm{d} 3.2, \mu \mathrm{m})$, specific surface area (SSA, $\left.\mathrm{m}^{2} / \mathrm{mL}\right)$, surface protein concentration $\left(\mathrm{SPC}\right.$, $\left.\mathrm{mg} / \mathrm{m}^{2}\right)$, rheological characteristics (flow and consistency indices) and physical creaming stability $(\mathrm{d} 4.3, \mu \mathrm{m})$ value at the top and bottom of tube after 9 days of storage at room temperature) of $\mathrm{O} / \mathrm{W}$ emulsions containing $4 \%(w / w)$ whey protein isolate plus sunflower and olive oils $(10 \%, 30 \%$ and $50 \%)$ and prepared by colloid mill (CM), conventional homogenization $(15 \mathrm{MPa})$ and ultra-high pressure homogenization at 100 and $200 \mathrm{MPa}$

\begin{tabular}{|c|c|c|c|c|c|c|c|c|}
\hline \multirow{3}{*}{ Pressure (MPa) } & \multirow{3}{*}{$\begin{array}{l}\text { Oil Content } \\
(\%)\end{array}$} & \multicolumn{2}{|c|}{ Droplet Size } & \multicolumn{2}{|c|}{ Rheological Behaviour } & \multirow{3}{*}{$\begin{array}{c}\begin{array}{c}\text { Surface } \\
\text { Coverage }\end{array} \\
\begin{array}{c}\text { Surface Protein } \\
\text { Concentration } \\
\text { (SPC) } \mathrm{mg} / \mathrm{m}^{2}\end{array}\end{array}$} & \multirow{2}{*}{\multicolumn{2}{|c|}{$\begin{array}{c}\text { Creaming Stability } \\
\begin{array}{c}\text { Emulsion Stability after } 9 \text { Days } \\
\text { (d4.3) }\end{array}\end{array}$}} \\
\hline & & \multirow{2}{*}{$\mathrm{d} 3.2(\mu \mathrm{m})$} & \multirow{2}{*}{$\begin{array}{c}\text { Specific Surface } \\
\text { Area SSA }\left(\mathrm{m}^{2} / \mathrm{mL}\right)\end{array}$} & \multirow{2}{*}{$\begin{array}{c}\text { Consistency } \\
\text { Coefficient }(K) \mathrm{mPa} \times \mathrm{s}\end{array}$} & \multirow{2}{*}{$\begin{array}{l}\text { Flow } \\
\text { Behaviour } \\
\text { Index }(n)\end{array}$} & & & \\
\hline & & & & & & & Top & Bottom \\
\hline \multirow{3}{*}{$\mathbf{C M}$} & 10 & $6.656 \pm 0.654^{\mathrm{A}}$ & $0.862 \pm 0.061^{\mathrm{B}}$ & $0.0016 \pm 0.0001^{\mathrm{h}}$ & $0.968 \pm 0.020$ & $27.04 \pm 7.17^{\mathrm{A}}$ & \multicolumn{2}{|c|}{ ND } \\
\hline & 30 & $6.132 \pm 0.166^{\mathrm{A}}$ & $0.979 \pm 0.027 \mathrm{~A}, \mathrm{~B}$ & $0.0025 \pm 0.0008^{g, h}$ & $1.105 \pm 0.087$ & $12.87 \pm 0.17^{\mathrm{B}}$ & \multicolumn{2}{|c|}{ ND } \\
\hline & 50 & $5.151 \pm 0.215^{\mathrm{B}}$ & $1.193 \pm 0.015^{\mathrm{A}}$ & $0.0185 \pm 0.0051^{\mathrm{f}}$ & $1.045 \pm 0.038$ & $6.85 \pm 0.95^{\mathrm{C}}$ & \multicolumn{2}{|c|}{ ND } \\
\hline \multirow{3}{*}{$\mathrm{CH}$} & 10 & $0.559 \pm 0.055^{\mathrm{b}}$ & $10.89 \pm 1.139^{\mathrm{e}}$ & $0.0017 \pm 0.0001^{\mathrm{h}}$ & $0.984 \pm 0.012$ & $2.37 \pm 0.41^{\mathrm{c}}$ & $0.907 \pm 0.037^{\mathrm{b}}$ & $0.487 \pm 0.061^{c, *}$ \\
\hline & 30 & $0.746 \pm 0.107^{\mathrm{a}}$ & $8.853 \pm 0.521^{\mathrm{e}}$ & $0.0051 \pm 0.0018 \mathrm{~g}$ & $0.973 \pm 0.021$ & $4.69 \pm 0.44^{\mathrm{a}}$ & $1.204 \pm 0.053^{\mathrm{a}, \mathrm{b}}$ & $0.775 \pm 0.046^{\mathrm{b}, *}$ \\
\hline & 50 & $0.699 \pm 0.036^{\mathrm{a}}$ & $8.537 \pm 0.450 \mathrm{e}$ & $0.5299 \pm 0.0696^{\mathrm{d}}$ & $0.596 \pm 0.152$ & $3.65 \pm 0.13^{b}$ & $1.411 \pm 0.194^{\mathrm{a}}$ & $1.436 \pm 0.191^{\mathrm{a}}$ \\
\hline \multirow{3}{*}{ UHPH 100 MPa } & 10 & $0.134 \pm 0.006^{\mathrm{e}}$ & $45.00 \pm 2.072^{b}$ & $0.0017 \pm 0.0001^{\mathrm{h}}$ & $0.984 \pm 0.013$ & $0.92 \pm 0.04^{\mathrm{d}}$ & $0.175 \pm 0.018^{\mathrm{d}}$ & $0.145 \pm 0.015^{f, g, *}$ \\
\hline & 30 & $0.141 \pm 0.007^{\mathrm{d}, \mathrm{e}}$ & $43.52 \pm 1.836^{\mathrm{b}, \mathrm{c}}$ & $0.4037 \pm 0.0008^{\mathrm{d}, \mathrm{e}}$ & $0.973 \pm 0.020$ & $0.85 \pm 0.01^{\mathrm{d}}$ & $0.186 \pm 0.016^{\mathrm{d}}$ & $0.183 \pm 0.014^{\mathrm{e}, \mathrm{f}}$ \\
\hline & 50 & $0.188 \pm 0.022^{c, d}$ & $34.24 \pm 2.259^{c, d}$ & $2.8961 \pm 0.7420^{\mathrm{b}}$ & $0.437 \pm 0.086$ & $1.16 \pm 0.02^{\mathrm{d}}$ & $0.267 \pm 0.021^{\mathrm{c}, \mathrm{d}}$ & $0.240 \pm 0.039 \mathrm{~d}, \mathrm{e}$ \\
\hline \multirow{3}{*}{ UHPH $200 \mathrm{MPa}$} & 10 & $0.103 \pm 0.006^{\mathrm{e}}$ & $60.81 \pm 1.903^{\mathrm{a}}$ & $0.0020 \pm 0.0003^{h}$ & $0.983 \pm 0.016$ & $0.88 \pm 0.07^{\mathrm{d}}$ & $0.117 \pm 0.009^{d}$ & $0.121 \pm 0.004^{g}$ \\
\hline & 30 & $0.123 \pm 0.010^{\mathrm{e}}$ & $51.38 \pm 2.380^{a, b}$ & $1.1960 \pm 0.0168^{c}$ & $0.882 \pm 0.087$ & $1.06 \pm 0.14^{\mathrm{d}}$ & $0.191 \pm 0.069^{\mathrm{d}}$ & $0.188 \pm 0.068^{e, f}$ \\
\hline & 50 & $0.214 \pm 0.033^{c}$ & $31.55 \pm 0.339^{\mathrm{d}}$ & $8.3300 \pm 1.108^{a}$ & $0.284 \pm 0.076$ & $1.18 \pm 0.13^{\mathrm{d}}$ & $0.422 \pm 0.118^{c}$ & $0.531 \pm 0.237^{c}$ \\
\hline
\end{tabular}

${ }^{a-h}$ Different letters in the same column (capital letters ( $\mathrm{A}, \mathrm{B} \ldots$ ) for comparison between $\mathrm{CM}$ emulsions and small letters (a b, ...) to compare between $\mathrm{CH}$ and UHPH emulsions) indicate significant differences between treatments (General Linear Models (GLM) with repeated measures, $p<0.05)$. Tukey correction was applied. * The sign indicates that the differences between the $\mathrm{d} 4.3(\mu \mathrm{m})$ at the top or at the bottom of emulsions are significant per level of pressure and oil concentration (Mann-Whitney-Wilcoxon test, $p<0.05)$. ND, not determined. 
With respect to the effect of oil concentration on the rheological flow behaviour, Newtonian behaviour $(n \approx 1)$ and low viscosities were observed in UHPH emulsions containing $10 \%(w / w)$ oil; however, when the oil content was increased to $30 \%(w / w)$, the K values significantly increased $(p<0.05)$ with a slight change in the rheological profile to shear-thinning behaviour in emulsions homogenized at $200 \mathrm{MPa}(n=0.88)$, but not in those treated at $100 \mathrm{MPa}$. An increase of oil concentration to $50 \%$ resulted in a large increase in the $K$ value, especially in emulsions treated at $200 \mathrm{MPa}$, and the flow index was altered to a high degree of pseudo-plasticity. Similar trends in the rheological characteristics have been reported [20] for emulsions prepared using UHPH and the same emulsifier (1.5\% whey proteins) with oil contents varying between $10 \%$ and $50 \%$ and [19] using $4 \%$ whey proteins and $15 \%-45 \%$ oil. In a study by Bellaltaa et al. [39], WPI emulsions sonicated at a nominal power level of $100 \mathrm{~W}$ for $180 \mathrm{~s}$ and containing $50 \%-55 \%$ oil showed Newtonian behaviour, but a further increase in the oil content to $60 \%$ changed the rheological behaviour to shear-thinning. They reported that, in emulsions with lower oil contents, the droplets are far apart and the inter-droplet interactions are relatively weaker. As oil content increases, the droplets are closer and the number density of droplets (number of droplets per unit volume of emulsions at a given dispersed phase volume fraction) increases. As a consequence, the mean distance of separation between droplets decreases, where London-van der Waals forces of attraction between droplets are dominant, leading to packing of the oil droplets and inter-droplet interactions and collisions. The flocculated droplets immobilize a significant amount of the continuous phase within themselves, which is released as the shear rate (or shear stress) increases. As a result, the effective dispersed-phase concentration decreases, which causes a decrease in the viscosity and the shear-thinning effect [40].

UHPH emulsions prepared with $50 \%(w / w)$ oil presented not only a shear-thinning behaviour, but also a thixotropic behaviour, as evidenced by hysteresis in Figure 3. The thixotropic behaviour of an emulsion indicates the existence of a structure that breaks down while shearing at a constant shear rate as a function of time followed by a gradual recovery when the shear is removed [41]. In this type of time-dependent fluid, a hysteresis loop can be observed when the sample is subjected to increasing and then reducing shear. $\mathrm{CH}$ and UHPH emulsions with 50\% oil content had a thixotropic behaviour, observed as a loop between the up and down curves, i.e., the samples behaved differently before and after shearing in the following order: $200 \mathrm{MPa}>\mathrm{CH}>100 \mathrm{MPa}$ (Figure 3).

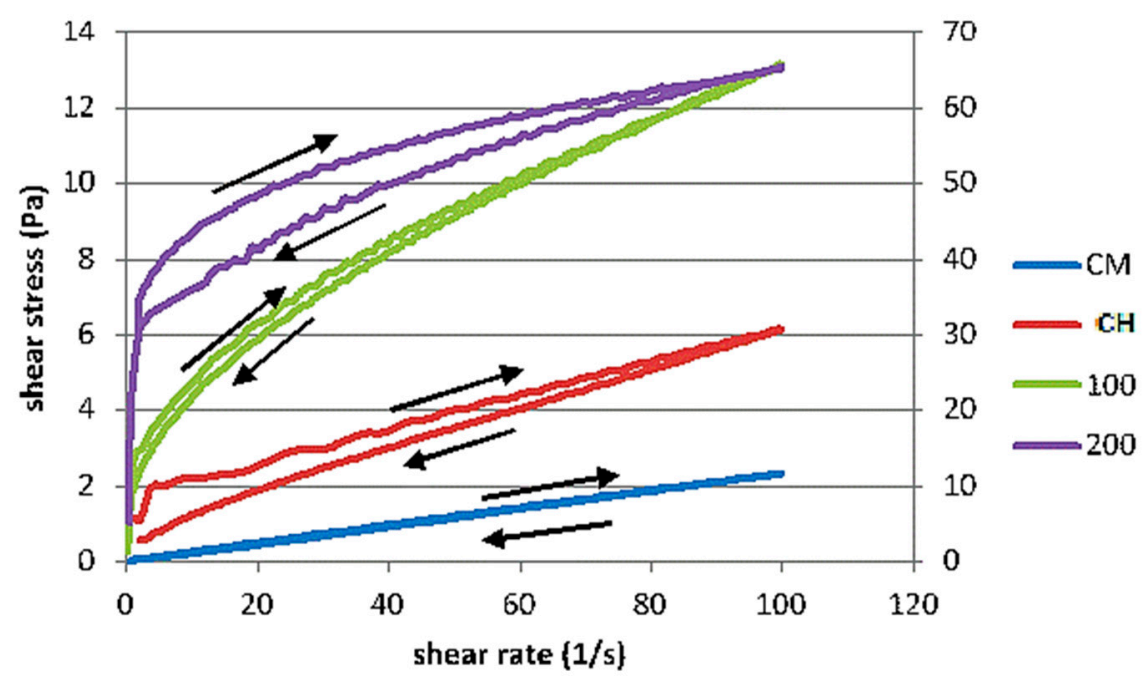

Figure 3. Hysteresis loops for O/W emulsions containing 50\% oil and WPI 4\% stabilized by CM (blue line), $\mathrm{CH}$ at $15 \mathrm{MPa}$ (red line) and by $\mathrm{UHPH}$ at $100 \mathrm{MPa}$ (green line) and $200 \mathrm{MPa}$ (purple line). 


\subsection{Stability of Emulsions to Creaming}

Creaming stability results using the $\mathrm{d} 4.3(\mu \mathrm{m})$ value at the top and bottom of emulsions stored at room temperature for nine days are presented in Table 2. The light scattering fingerprints obtained by Turbiscan analysis of CM, CH and UHPH emulsions with oil concentrations of $10 \%$ and $50 \% w / w$ are shown in Figure 4.
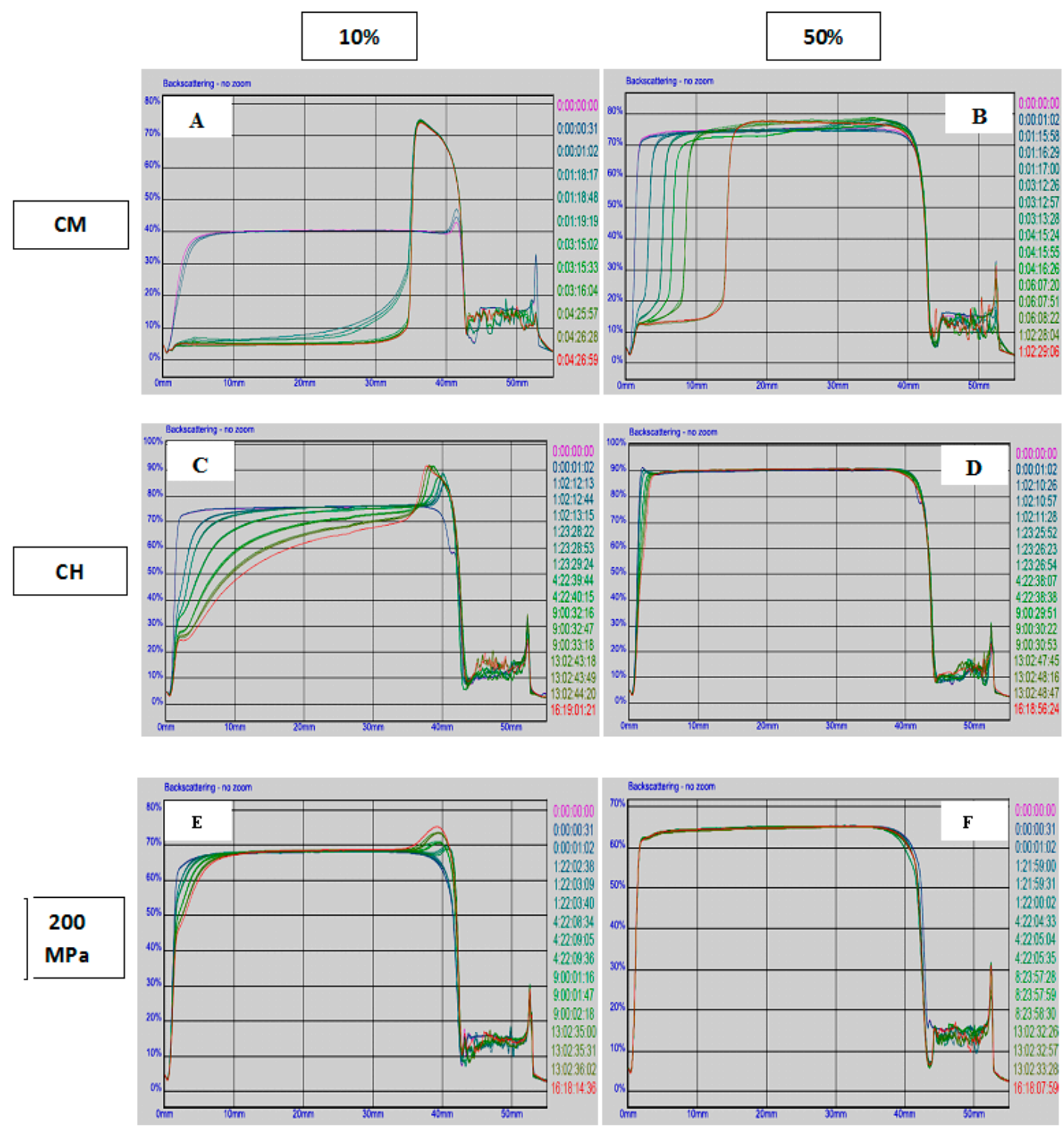

Figure 4. Changes in backscattering profiles (BS\%) (A-F) of emulsions containing $4 \%$ of WPI and different oil contents, $10 \%(\mathbf{A}, \mathbf{C}, \mathbf{E})$ and $50 \%$ (B,D,F), prepared by colloidal mill (A,B), conventional homogenization (C,D) and UHPH treated at $200 \mathrm{MPa}(\mathbf{E}, \mathbf{F})$, as a function of sample height with storage time ( $5 \mathrm{~h}$ for $\mathrm{CM}$ emulsions and 17 days for both $\mathrm{CH}$ and $\mathrm{UHPH}$ emulsions).

Low creaming stability could be observed in CM emulsions. Possible reasons for this could be their high droplet size (the larger the droplets, the faster the creaming [42]), their high interfacial tension between oil droplets because no protective protein layer exists surrounding the oil droplets, their low viscosity and their high coalescence rate, as previously described. A great variation in physical stability with time could be observed in the backscattering profiles for CM emulsions containing 10\% oil, with the emulsion being totally separated after $\sim 1 \mathrm{~h}$. CM emulsions containing 50\% oil exhibited 
higher stability to creaming and lower separation rate with time. These results were validated by the migration velocity $V(t)(\mu \mathrm{m} / \mathrm{min})$ of droplets to the top of the samples, which was calculated with the Turbiscan equipment. Migration velocity was reduced in emulsions containing 50\% oil (37.1 $\mu \mathrm{m} / \mathrm{min})$, in comparison to those containing $10 \%$ and $30 \%$ oil $(273.6$ and $79.3 \mu \mathrm{m} / \mathrm{min}$, respectively). This higher stability may be explained by a significantly lower droplet size $(p<0.05)$, higher viscosity and better protein coverage of CM emulsions containing 50\% oil.

Data in Table 2 and Figure 4C-F show the physical stability of $\mathrm{CH}$ and UHPH emulsions. $\mathrm{CH}$ emulsions exhibited high stability to creaming, especially those containing 30\% and 50\% oil, presenting lower migration velocity of droplets $(120.4,18.6$ and $17.7 \mu \mathrm{m} / \mathrm{min}$ for $\mathrm{CH}$ emulsions containing $10 \%, 30 \%$ and $50 \%$ oil, respectively). Creaming was visually observed in $\mathrm{CH}$ emulsions containing $10 \%$ and $30 \%$ oil, but not in emulsions containing 50\% oil. These results were also confirmed by the $\mathrm{d} 4.3(\mu \mathrm{m})$ value at the top or at the bottom of emulsions, where differences were significant $(p<0.05)$ in emulsions containing $10 \%$ and $30 \%$ oil, but not in those containing 50\% oil (Table 2 ). Conventional emulsions are thermodynamically unstable systems because of the positive free energy associated with the contact of oil and water phases, as manifested by a relatively high positive interfacial tension [43].

All UHPH emulsions remained fully turbid along the tube during the 17 days of storage without any visual changes or phase separation. Generally, UHPH led to excellent oil droplet stability to creaming for all model emulsions. For instance, the migration velocity value for UHPH emulsions treated at $200 \mathrm{MPa}$ and containing $10 \%$ oil $(15.2 \mu \mathrm{m} / \mathrm{min})$ was much lower than those of $\mathrm{CM}$ and $\mathrm{CH}$ emulsions with the same oil content (273.6 and $120.4 \mu \mathrm{m} / \mathrm{min}$, respectively). UHPH-treated emulsions at $200 \mathrm{MPa}$ seemed to be much more stable than those treated at $100 \mathrm{MPa} . \mathrm{d} 4.3(\mu \mathrm{m})$ values at the top and at the bottom of UHPH emulsions indicated a slight creaming effect in emulsions with 10\% oil treated at $100 \mathrm{MPa}$ compared to those containing 30\% and 50\% oil (Table 2). However, all emulsions treated at $200 \mathrm{MPa}$ were more stable to creaming independently of oil concentration with no significant differences $(p<0.05)$ between top and bottom $\mathrm{d} 4.3(\mu \mathrm{m})$ values (Table 2$)$.

High-pressure homogenization improves the creaming stability of emulsions by decreasing droplet size according to Stoke's law, which in turn increases the density of droplets and concomitantly the viscosity of the emulsion, slowing down the droplet movement [44]. The obtained results for UHPH emulsions are in agreement with the results found by Cortés-Muñoz et al. [19]. These researchers observed a slight creaming effect in emulsions with $15 \%(w / w)$ of oil, in comparison to those containing $30 \%$ and $45 \%$, and treated at 100-150 MPa. However, UHPH treatment at $200 \mathrm{MPa}$ led to excellent oil droplet stability to creaming and coalescence, especially when a high oil concentration was used. Other studies [12] reported that UHPH emulsions treated at $100 \mathrm{MPa}$, compared to 200 and $300 \mathrm{MPa}$, exhibited greater clarification and creaming, which also supports the results of the present study.

Increasing the oil concentration significantly reduced creaming $(p<0.05)$. As might be expected, larger droplets result in less stable emulsions. However, for the same droplet sizes, oil content also plays an important role [45]. These authors reported that a larger amount of oil in the emulsion $(40 \%)$ resulted in a more stable system in comparison to a small oil amount (20\%). For $20 \%$ O/W emulsions with larger droplets, the crystallization was promoted, producing emulsions with large fat crystals, which may result in partial coalescence in the emulsion [46]. However, crystallization was promoted in $40 \% \mathrm{O} / \mathrm{W}$ emulsions with a small droplet size where only small fat crystals are formed through a homogeneous nucleation, which in combination with the emulsifier, stabilizes the interface of the emulsion droplets [47]. Another explanation for the lower tendency to creaming in emulsions containing higher amounts of oil, either in the conventional or in the UHPH emulsions, could be the increase in the viscosity of the continuous phase that surrounds the oil droplets, restricting the movement of droplets. Cortés-Muñoz et al. [19] reported high stability at higher oil concentrations than at lower oil concentrations. Fernández-Ávila [12], who also found similar results to those of the present study, reported that UHPH emulsions containing 20\% $(v / v)$ oil were more stable to creaming than those containing $10 \%(v / v)$ oil. They also reported that after more than five months of cold 
storage, emulsions containing $20 \%(v / v)$ and treated at 100 or $200 \mathrm{MPa}$ did not show any differences in creaming. This fact was explained by the lack of larger aggregates in fresh emulsions, as well as the depletion flocculation of protein-coated droplets by unadsorbed proteins in the aqueous phase.

\subsection{Oxidative Stability}

Hydroperoxide content and TBARS values of $4 \%$ of WPI emulsions containing different oil concentrations and treated by either $\mathrm{CM}, \mathrm{CH}$ or UHPH are shown in Table 3. The results of the present study showed that CM emulsions, which had large droplet sizes and low SSA values, were more prone to oxidation than the corresponding $\mathrm{CH}$ and $\mathrm{UHPH}$ emulsions. Similar results have been reported in a previous study with emulsions produced under the same conditions with whey protein isolate [23]. Atarés et al. [48], using a high-pressure jet homogenizer at $30 \mathrm{MPa}$, evaluated the structure and oxidative stability of $\mathrm{O} / \mathrm{W}$ emulsions formulated with whey protein and sunflower oil in the presence of flavonoid rutin. It was found that high-pressure homogenization, through droplet size reduction, stabilized the emulsions against both creaming and oil oxidation. These studies suggest that SSA is not the only determining factor of the oxidative stability of emulsions.

High levels of primary and secondary oxidation products were observed in CM emulsions. The high hydroperoxide value in combination with the high levels of TBARS obtained, especially those $\mathrm{CM}$ emulsions containing $10 \%$ or $50 \%$ oil, indicates the progression of oxidation from a primary to a secondary state. This high sensitivity of $\mathrm{CM}$ emulsions to lipid oxidation could be due to their low protein coverage (Figure $1 \mathrm{~B}(\mathrm{ii})$ ) and high coalescence rate in comparison to $\mathrm{CH}$ and $\mathrm{UHPH}$ emulsions, as previously described.

$\mathrm{CH}$ emulsions exhibited an intermediate oxidation level between CM and UHPH emulsions. At Day 10 of storage, $\mathrm{CH}$ emulsions containing $10 \%$ and $50 \%$ oil presented significantly higher $(p<0.05)$ amounts of hydroperoxides in comparison to those containing $30 \%$ oil. Furthermore, the secondary oxidation products also increased as the oil content increased, although the differences in TBARS were not significant $(p<0.05)$ between different oil concentrations.

UHPH emulsions presented the best oxidative stability. When comparing UHPH pressures, although not significant $(p<0.05)$, emulsions treated at $100 \mathrm{MPa}$ seem to be slightly less oxidized than those treated at $200 \mathrm{MPa}$. All UHPH treatments independently of oil content showed a significant increase $(p<0.05)$ in hydroperoxide content between Day 1 and Day 10 of storage, except for UHPH treatment at $200 \mathrm{MPa}$ of emulsions with $10 \%$ oil. However, taking into account the TBARS values, the latter sample was the only UHPH treatment at $200 \mathrm{MPa}$ showing a significant increase $(p<0.05)$ during storage. The higher oxidation rate observed in UHPH emulsions treated at $200 \mathrm{MPa}$, compared to those treated at $100 \mathrm{MPa}$, could be due to the decrease in the ability of whey proteins to protect the oil droplets with increasing pressure of the treatment, which may be related to the increase in the product temperature that takes place during UHPH treatment at the outlet of the homogenization valve.

Similar results were found in a previous study of the present authors [23] on systems containing WPI at different concentrations $(1 \%, 2 \%$ and $4 \%)$ with $20 \%$ oil, in which UHPH-treated emulsions at $100 \mathrm{MPa}$ were more stable to oxidation than those treated at 200 or $300 \mathrm{MPa}$. It was reported that treating emulsions at $100 \mathrm{MPa}$ caused partial denaturation and/or aggregation of whey proteins resulting in the dissociation of large aggregates, which in turn resulted in an increased surface hydrophobicity of $\beta$-Lg. This increase in hydrophobicity may allow more of the protein to pack at the surface of the emulsion droplets, thereby providing better protection against oxidation.

Over a 10-day storage, all samples showed an increase in primary oxidation products, except for emulsions with $10 \%$ oil treated at $200 \mathrm{MPa}$. However, a significant increase $(p<0.05)$ was only observed in emulsions with $50 \%$ oil treated at $100 \mathrm{MPa}$ and emulsions with $10 \%$ and $30 \%$ oil treated at $200 \mathrm{MPa}$. This indicates that increasing the oil content to $50 \%$ negatively affects the oxidative stability at this UHPH pressure. 
Table 3. Mean \pm standard deviation of the amount of hydroperoxides (absorbance at $510 \mathrm{~nm}$ ) and thiobarbituric acid-reactive substances (TBARS) ( $\mu$ g/mL) of $\mathrm{O} / \mathrm{W}$ emulsions containing $4 \%(w / w)$ of whey protein isolate plus sunflower and olive oils $(10 \%, 30 \%$ and $50 \%)$ and prepared by colloid mill (CM), conventional homogenization (15 MPa) and ultra-high pressure homogenization at 100 and $200 \mathrm{MPa}$.

\begin{tabular}{|c|c|c|c|c|c|c|c|}
\hline \multirow[b]{2}{*}{ Pressure (MPa) } & \multirow{2}{*}{$\begin{array}{c}\text { Oil content } \\
(\%)\end{array}$} & \multicolumn{3}{|c|}{ Hydroperoxides (ABS $510 \mathrm{~nm}$ ) } & \multicolumn{3}{|c|}{ TBARS $(\mu \mathrm{g} / \mathrm{mL})$} \\
\hline & & Day 1 & Day 10 & $\begin{array}{c}\text { Difference (Day } \\
\text { 10-Day 1) }\end{array}$ & Day 1 & Day 10 & Difference (Day 10-Day 1) \\
\hline \multirow{3}{*}{$\mathrm{CM}$} & 10 & $0.017 \pm 0.004^{\mathrm{c}}$ & $0.326 \pm 0.195^{\mathrm{a}, \mathrm{b}}$ & $0.309 \pm 0.198^{a, *}$ & $0.097 \pm 0.016^{\mathrm{a}}$ & $0.143 \pm 0.017^{\mathrm{a}, \mathrm{b}}$ & $0.046 \pm 0.031^{\mathrm{a}, \mathrm{b} *}$ \\
\hline & 30 & $0.039 \pm 0.005^{a, b, c}$ & $0.333 \pm 0.026^{\mathrm{a}, \mathrm{b}}$ & $0.294 \pm 0.022^{a, *}$ & $0.060 \pm 0.003^{b, c, d}$ & $0.079 \pm 0.003^{c, d, e}$ & $0.020 \pm 0.004^{\mathrm{a}, \mathrm{b}, \mathrm{c}, \mathrm{d} *}$ \\
\hline & 50 & $0.078 \pm 0.003^{\mathrm{a}}$ & $0.433 \pm 0.063^{\mathrm{a}}$ & $0.356 \pm 0.063^{a, *}$ & $0.100 \pm 0.007^{\mathrm{a}}$ & $0.160 \pm 0.022^{\mathrm{a}}$ & $0.061 \pm 0.017^{\mathrm{a} *}$ \\
\hline \multirow{3}{*}{$\mathrm{CH}$} & 10 & $0.039 \pm 0.015^{\mathrm{a}, \mathrm{b}, \mathrm{c}}$ & $0.252 \pm 0.032^{\mathrm{a}, \mathrm{b}}$ & $0.213 \pm 0.047^{\mathrm{a}, \mathrm{b} *}$ & $0.054 \pm 0.002^{b, c, d}$ & $0.075 \pm 0.007^{\mathrm{c}, \mathrm{d}, \mathrm{e}}$ & $0.021 \pm 0.007^{\mathrm{a}, \mathrm{b}, \mathrm{c}, \mathrm{d} *}$ \\
\hline & 30 & $0.041 \pm 0.023^{a, b, c}$ & $0.178 \pm 0.012^{\mathrm{c}}$ & $0.137 \pm 0.034^{\mathrm{a}, \mathrm{b} *}$ & $0.058 \pm 0.004^{b, c, d}$ & $0.092 \pm 0.009^{c, d}$ & $0.034 \pm 0.006^{\mathrm{a}, \mathrm{b}, \mathrm{c}, \mathrm{d} *}$ \\
\hline & 50 & $0.057 \pm 0.029^{a, b}$ & $0.245 \pm 0.048^{\mathrm{a}, \mathrm{b}}$ & $0.187 \pm 0.074^{\mathrm{a}, \mathrm{b} *}$ & $0.068 \pm 0.005^{b, c}$ & $0.110 \pm 0.035^{b, c}$ & $0.041 \pm 0.034^{\mathrm{a}, \mathrm{b}, \mathrm{c} *}$ \\
\hline \multirow{3}{*}{ UHPH $100 \mathrm{MPa}$} & 10 & $0.022 \pm 0.004^{b, c}$ & $0.027 \pm 0.004^{c, d}$ & $0.005 \pm 0.004^{b, c *}$ & $0.052 \pm 0.004^{\mathrm{c}, \mathrm{d}}$ & $0.044 \pm 0.003^{\mathrm{e}}$ & $-0.08 \pm 0.003^{\mathrm{e} *}$ \\
\hline & 30 & $0.026 \pm 0.006^{b, c}$ & $0.034 \pm 0.0008^{\mathrm{c}, \mathrm{d}}$ & $0.009 \pm 0.006 b^{c *}$ & $0.051 \pm 0.004^{\mathrm{c}, \mathrm{d}}$ & $0.040 \pm 0.008^{\mathrm{e}}$ & $-0.011 \pm 0.008^{\mathrm{e} *}$ \\
\hline & 50 & $0.028 \pm 0.009 \mathrm{~b}, \mathrm{c}$ & $0.033 \pm 0.009^{c, d}$ & $0.0049 \pm 0.004 b^{c *}$ & $0.041 \pm 0.009^{d}$ & $0.053 \pm 0.008^{\mathrm{d}, \mathrm{e}}$ & $0.012 \pm 0.006^{\mathrm{b}, \mathrm{c}, \mathrm{d} *}$ \\
\hline \multirow{3}{*}{ UHPH $200 \mathrm{MPa}$} & 10 & $0.025 \pm 0.004^{b, c}$ & $0.024 \pm 0.003^{\mathrm{d}}$ & $0.00 \pm 0.0016^{c}$ & $0.054 \pm 0.008^{b, c, d}$ & $0.088 \pm 0.006^{c, d}$ & $0.034 \pm 0.011^{\mathrm{a}, \mathrm{b}, \mathrm{c}, \mathrm{d} *}$ \\
\hline & 30 & $0.019 \pm 0.006^{b, c}$ & $0.037 \pm 0.003^{c, d}$ & $0.018 \pm 0.004^{b *}$ & $0.059 \pm 0.008^{b, c, d}$ & $0.066 \pm 0.013^{\mathrm{d}, \mathrm{e}}$ & $0.006 \pm 0.017^{b, c, d}$ \\
\hline & 50 & $0.032 \pm 0.006^{b, c}$ & $0.038 \pm 0.004^{c}$ & $0.006 \pm 0.004^{b, c *}$ & $0.072 \pm 0.007^{\mathrm{b}}$ & $0.072 \pm 0.004^{\mathrm{c}, \mathrm{d}, \mathrm{e}}$ & $0.00 \pm 0.009 \mathrm{c}, \mathrm{d}$ \\
\hline
\end{tabular}

${ }^{a-e}$ Different letters in the same column indicate significant differences between treatments (GLM with repeated measures, $\left.p<0.05\right)$. Tukey correction was applied. ${ }^{*}$ The sign indicates that the differences in oxidation products between Day 10 and Day 1 are significant per level of pressure and oil concentration (Wilcoxon test, $p<0.05$ ). 
The obtained results in agreement with those previously reported for safflower oil [44], canola oil [49], menhaden oil [34] and walnut oil [50], in which the oil-phase volume fraction played a dominant role in determining the oxidative stability, increasing the oil content negatively affected the oxidative stability of emulsions. Sun and Gunasekaran [34] found that $40 \%(v / v) \mathrm{O} / \mathrm{W}$ emulsions had slightly higher peroxide values than $20 \% v / v \mathrm{O} / \mathrm{W}$ emulsions in the $0.2 \%$ WPI-stabilized emulsions. Gharibzahedi et al. [50], studying different concentrations of walnut oil, observed that the emulsions with high oil contents had the highest peroxide values.

\section{Conclusions}

The results of the present study revealed the potential of the UHPH technology in the production of submicron emulsions with high physical and oxidative stability, including those containing large concentrations of oil (e.g., up to $50 \%$ oil).

Emulsions produced with a colloid mill were more prone to creaming and oxidation compared to those produced by conventional homogenization and UHPH. Increasing oil concentration in the former emulsions significantly decreased $(p<0.05)$ droplet size and improved creaming stability. On the contrary, for conventional homogenization and UHPH emulsions, an increase in the droplet size was observed as oil content increased from $10 \%-30 \%$ and $50 \%$. Furthermore, increases in oil concentration in these emulsions caused a change in the rheological behaviour from Newtonian to shear-thinning flow (with evidence of thixotropy). High oxidative stability was achieved with conventional homogenization and UHPH compared to colloid milling. UHPH emulsions with 30\% oil treated at $100 \mathrm{MPa}$ presented the best oxidative stability of all of the emulsions studied. Conventional homogenization resulted in higher levels of hydroperoxides than UHPH during storage, but similar levels of TBARS. The high physical and oxidative stability of UHPH-treated submicron emulsions suggests that UHPH might have a great potential in increasing the shelf-life of food products rich in polyunsaturated fatty acids.

Acknowledgments: The authors thank the Ministry of Research, Development and Innovation (Ministry of Economy and Competitiveness) for the financial support provided for this research (AGL2011-26766). The authors are grateful to the personnel of the Servei de Microscopia of Universitat Autònoma de Barcelona (UAB), for their excellent technical support. Essam Hebishy thanks the Spanish Agency for International Cooperation for Development (Ministry of Foreign Affairs and Cooperation) for the grant awarded to develop this research.

Author Contributions: Essam Hebishy, Martin Buffa and Antonio-Jose Trujillo conceived of and designed the experiments. Essam Hebishy performed the experiments. Anabel Blasco-Moreno and Anna Zamora analysed the data. Essam Hebishy, Anna Zamora and Antonio-Jose Trujillo wrote the paper.

Conflicts of Interest: The authors declare no conflict of interest.

\section{References}

1. Tonon, R.V.; Grosso, C.R.F.; Hubinger, M.D. Influence of emulsion composition and inlet air temperature on the microencapsulation of flaxseed oil by spray drying. Food Res. Int. 2011, 44, 282-289. [CrossRef]

2. Gunstone, F.D.; Martini, S. Chemical and physical deterioration of bulk oils and shortenings, spreads and frying oils. In Chemical Deterioration and Physical Instability of Food and Beverages; Skibsted, L.H., Risbo, J., Andersen, M.L., Eds.; Woodhead Publishing Limited: Woodhead Publishing Limited, UK, 2010; pp. 413-438.

3. Cornacchia, L.; Roos, Y.H. State of dispersed lipid carrier and interface composition as determinants of beta-carotene stability in oil-in-water emulsions. J. Food Sci. 2011, 76, 1211-1218. [CrossRef] [PubMed]

4. Troncoso, E.; Aguilera, J.M.; McClements, D.J. Fabrication, characterization and lipase digestibility of food-grade nanoemulsions. Food Hydrocoll. 2012, 27, 355-363. [CrossRef]

5. Becher, P. Emulsions: Theory and Practice; Oxford University Press, Inc.: New York, NY, USA, 2001.

6. Mason, T.G.; Wilking, J.N.; Meleson, K.; Chang, C.B.; Graves, S.M. Nanoemulsions: Formation, structure, and physical properties. J. Phys. Condens. Matter 2006, 18, 635-666. [CrossRef]

7. Jafari, S.M.; Assadpoor, E.; Bhandari, B.; He, Y. Recoalescence of emulsion droplets during high-energy emulsification. Food Hydrocoll. 2008, 22, 1191-1202. [CrossRef] 
8. Gutierrez, J.M.; Gonzalez, C.; Maestro, A.; Solè, I.; Pey, C.M.; Nolla, J. Nanoemulsions: New applications and optimization of their preparation. Curr. Opin. Colloid 2008, 13, 245-251. [CrossRef]

9. Picart, L.; Thiebaud, M.; René, M.; Guiraud, J.P.; Cheftel, J.C.; Dumay, E. Effects of high pressure homogenisation of raw bovine milk on alkaline phosphatase and microbial inactivation. A comparison with continuous short time thermal treatments. J. Dairy Res. 2006, 73, 454-463. [CrossRef] [PubMed]

10. Thiebaud, M.; Dumay, E.; Picart, L.; Guiraud, J.P.; Cheftel, J.C. High-pressure homogenisation of raw bovine milk. Effects on fat globule size distribution and microbial inactivation. Int. Dairy J. 2003, 13, 427-439. [CrossRef]

11. Martínez-Monteagudo, S.I.; Kamat, S.; Patel, N.; Konuklar, G.; Rangavajla, N.; Balasubramaniam, V.M. Improvements in emulsion stability of dairy beverages treated by high pressure homogenization: A pilot-scale feasibility study. J. Food Eng. 2017, 193, 42-52.

12. Fernández-Ávila, C.; Escriu, R.; Trujillo, A.J. Ultra-high pressure homogenization enhances physicochemical properties of soy protein isolate-stabilized emulsions. Food Res. Int. 2015, 75, 357-366. [CrossRef]

13. Kuhn, K.R.; Cunha, R.L. Flaxseed oil-Whey protein isolate emulsions: Effect of high pressure homogenization. J. Food Eng. 2012, 111, 449-457. [CrossRef]

14. McClements, D.J. Protein-stabilized emulsions. Curr. Opin. Colloid Interface Sci. 2004, 9, 305-313. [CrossRef]

15. Livney, Y.D. Milk proteins as vehicles for bioactives. Curr. Opin. Colloid Interface Sci. 2010, 15, 73-83. [CrossRef]

16. Paraskevopoulou, D.; Boskou, D.; Paraskevopoulou, A. Oxidative stability of olive oil-lemon juice salad dressings stabilized with polysaccharides. Food Chem. 2007, 101, 1197-1204. [CrossRef]

17. McClements, D.J.; Decker, E.A. Lipid oxidation in oil-in-water emulsions: Impact of molecular environment on chemical reactions in heterogeneous food systems. J. Food Sci. 2000, 65, 1270-1282. [CrossRef]

18. Soleimanpour, M.; Koocheki, A.; Kadkhodaee, R. Influence of main emulsion components on the physical properties of corn oil in water emulsion: Effect of oil volume fraction, whey protein concentrate and Lepidium perfoliatum seed gum. Food Res. Int. 2013, 50, 457-466. [CrossRef]

19. Cortés-Muñoz, M.; Chevalier-Lucia, D.; Dumay, E. Characteristics of submicron emulsions prepared by ultra-high-pressure homogenization: Effect of chilled or frozen storage. Food Hydrocoll. 2009, 23, 640-654.

20. Floury, J.; Desrumaux, A.; Lardieres, J. Effect of high-pressure homogenization on droplet size distributions and rheological properties of model oil-in-water emulsion. Innov. Food Sci. Emerg. Technol. 2000, 1, 127-134. [CrossRef]

21. McClements, D.J.; Li, Y. Structured emulsion-based delivery systems: Controlling the digestion and release of lipophilic food components. Adv. Colloid Interface Sci. 2010, 159, 213-228. [CrossRef] [PubMed]

22. Berton-Carabin, C.C.; Ropers, M.-H.; Genot, C. Lipid oxidation in oil-in-water emulsions: Involvement of the interfacial layer. Compr. Rev. Food Sci. Food Saf. 2014, 13, 945-977. [CrossRef]

23. Hebishy, E.; Buffa, M.; Guamis, B.; Blasco-Moreno, A.; Trujillo, A.-J. Physical and oxidative stability of whey protein oil-in-water emulsions produced by conventional and ultra high-pressure homogenization: Effects of pressure and protein concentration on emulsion characteristics. Innov. Food Sci. Emerg. Technol. 2015, 32, 79-90. [CrossRef]

24. Fernandez-Avila, C.; Trujillo, A.J. Ultra-High Pressure Homogenization improves oxidative stability and interfacial properties of soy protein isolate-stabilized emulsions. Food Chem. 2016, 209, 104-113. [CrossRef] [PubMed]

25. Hemar, Y.; Tamehana, M.; Munro, P.A.; Singh, H. Influence of xanthan gum on the formation and stability of sodium caseinate oil-in-water emulsions. Food Hydrocoll. 2001, 15, 513-519. [CrossRef]

26. Desrumaux, A.; Marcand, J. Formation of sunflower oil emulsions stabilized by whey proteins with high-pressure homogenization (up to $350 \mathrm{MPa}$ ): Effect of pressure on emulsion characteristics. Int. J. Food Sci. Technol. 2002, 37, 263-269. [CrossRef]

27. Cruz, N.; Capellas, M.M.; Hernández, M.; Trujillo, A.J.; Guamis, B.; Ferragut, V. Ultra high pressure homogenization of soymilk: microbial, physicochemical and microstructural characteristics. Food Res. Int. 2007, 40, 725-732. [CrossRef]

28. Shantha, N.C.; Decker, E.A. Rapid sensitive iron based spectrophotometric methods for the determination of peroxide values in food lipids. J. Assoc. Off. Anal. Chem. Int. 1994, 77, 421-424.

29. McDonald, R.E.; Hultin, H.O. Some characteristics of the enzyme lipid peroxidation systems in the microsomal fraction of flounder muscle. J. Food Sci. 1987, 52, 15-21, 27. [CrossRef] 
30. Pereda, J.; Ferragut, V.; Quevedo, J.M.; Guamis, B.; Trujillo, A.J. Effects of ultra-high pressure homogenization on microbial and physicochemical shelf life of milk. J. Dairy Sci. 2007, 90, 1081-1093. [CrossRef]

31. Jafari, S.M.; He, Y.; Bhandari, B. Optimization of nano-emulsions production by microfluidization. Eur. Food Res. Technol. 2009, 225, 733-741. [CrossRef]

32. Seekkuarachchi, I.N.; Tanaka, K.; Kumazawa, H. Formation and charaterization of submicrometer oil-in-water (O/W) emulsions, using high-energy emulsification. Ind. Eng. Chem. Res. 2006, 45, 372-390. [CrossRef]

33. Desrumaux, A.; Loisel, C.; Marcand, J. Performances of a new high pressure homogenizer to make fine food emulsions. In Proceedings of the 8th International Congress on Engineering and Food (ICEF), Puebla, Mexico, 9-13 April 2000.

34. Sun, C.; Gunasekaran, S. Effects of protein concentration and oil-phase volume fraction on the stability and rheology of menhaden oil-in-water emulsions stabilized by whey protein isolate with xanthan gum. Food Hydrocoll. 2009, 23, 165-174. [CrossRef]

35. McClements, D.J. Food Emulsions: Principles, Practices, and Techniques, 2nd ed.; CRC Press: Boca Raton, FL, USA, 2000.

36. Dalgleish, D.G. Emulsion and Emulsion Stability; Sjöblom, J., Ed.; Marcel Dekker: New York, NY, USA, 1996.

37. Dickinson, E. An Introduction to Food Colloids; Oxford University Press: Oxford, UK, 1992.

38. Denda, A.; Hayashi, R. Emulsifying properties of pressure-treated proteins. In High Presure and Biotechnology; Balny, C., Hayashi, R., Heremans, K., Masson, P., Eds.; John Libbey Eurotext Ltd.: Montrouge, France; Volume 224, pp. 333-335.

39. Bellaltaa, P.; Troncosob, E.; Zúñigac, R.N.; Aguilerab, J.M. Rheological and microstructural characterization of WPI-stabilized o/w emulsions exhibiting time-dependent flow behavior. LWT_Food Sci. Technol. 2012, 46, 375-381. [CrossRef]

40. Kundu, P.; Kumar, V.; Mishra, I.M. Modelling the steady-shear rheological behavior of dilute to highly concentrated oil-in-water $(\mathrm{o} / \mathrm{w})$ emulsions: Effect of temperature, oil volume fraction and anionic surfactant concentration. J. Pet. Sci. Eng. 2015, 129, 189-204. [CrossRef]

41. Petrovic, L.B.; Sovilj, V.J.; Katona, J.M.; Milanovic, J.L. Influence of polymer surfactant interactions on o/w emulsion properties and microcapsule formation. J. Colloid Interface Sci. 2010, 342, 333-339. [CrossRef] [PubMed]

42. Perrechil, F.A.; Cunha, R.L. Oil-in-water emulsions stabilized by sodium caseinate: influence of $\mathrm{pH}$, high-pressure homogenization and locust bean gum addition. J. Food Eng. 2010, 97, 441-448. [CrossRef]

43. Friberg, S.E.; Larsson, K.; Sjobolom, J. Food Emulsions, 4th ed.; Marcel Dekker: New York, NY, USA, 2004.

44. Sims, R.J.; Fioriti, J.A.; Trumbetas, J. Effect of sugars and sugar alcohols on autoxidation of safflower oil in emulsions. J. Am Oil Chem. Soci. 1979, 56, 742-745. [CrossRef]

45. Tippetts, M.; Martini, S. Effect of cooling rate on the thermal behaviour and physicochemical stability of oil-in-water emulsions. Food Res. Int. 2009, 42, 847-855. [CrossRef]

46. Rousseau, D. Fat crystals and emulsion stability-A review. Food Res. Int. 2000, 33, 3-14. [CrossRef]

47. Hartel, R.W. Chapter 5: Nucleation. In Crystallisation in Foods; Aspen Publishers, Inc.: Gaithersburg, MD, USA, 2001; pp. 145-191.

48. Atarés, L.; Marshall, L.J.; Akhtar, M.; Murray, B.S. Structure and oxidative stability of oil in water emulsions as affected by rutin and homogenization procedure. Food Chem. 2012, 134, 1418-1424. [CrossRef] [PubMed]

49. Osborn, H.T.; Akoh, C.C. Effect of emulsifier type, droplet size, and oil concentration on lipid oxidation in structured lipid-based oil-in-water emulsions. Food Chem. 2004, 84, 451-456. [CrossRef]

50. Gharibzahedi, S.M.T.; Mousavi, S.M.; Hamedi, M.; Khodaiyan, F.; Razavi, S.H. Development of an optimal formulation for oxidative stability of walnut beverage emulsions based on gum arabic and xanthan gum using response surface methodology. Carbohyd. Poly. 2012, 87, 1611-1619. [CrossRef]

(C) 2017 by the authors; licensee MDPI, Basel, Switzerland. This article is an open access article distributed under the terms and conditions of the Creative Commons Attribution (CC BY) license (http:/ / creativecommons.org/licenses/by/4.0/). 